\title{
POPULATION OUTBURST OF MECOPODA ELONGATA LINN. (ORTHOPTERA: TETTIGONIIDAE) AROUND PUNE, MAHARASHTRA
}

\author{
R.M. Sharma, P.P. Kulkarni and R.H. Kamble
}

Zoological Survey of India, Western Regional Station, P.Box No. 3053, Vidyanagar, Sector 29, Akurdi, Pune, Maharashtra 411044, India

During the course of our observations and collections of insects attracted to light (metal halloid sodium lamps of 500 Watt.) in the premises of the Zoological Survey of India at Akurdi (about 30 $\mathrm{km}$. from Pune), we witnessed a population outburst of the Longhorned Grasshopper Mecopoda elongata Linn. on the night of 12.xi.1998. It was comparatively a warm day (temp. max. $31.2^{\circ} \mathrm{C}$ $(+1)$ and $\min .21 .4^{\circ} \mathrm{C}(+7)$; humidity was $65 \%$ (departure $\left.+24 \%\right)$ ); sky was partly cloudy with a spell of rain in some parts of Pune.

Approximately 750-800 individuals (females outnumbered the males) were attracted to the lamp. The maximum congregation was around $2200 \mathrm{hr}$. In fact, the lawn in front of the building appeared to be littered with dead leaves due to the grasshopper's deceptive colouration. All the individuals were resting head downwards and hind portion raised up. Surprisingly, they were not much active and their leaps very short.

Several species of insects are known to get attracted to light. A perusal of literature of this subject especially that of Shull and Nadkerny (1967) reveals that a large number of insect species of different orders, including 26 species of Short-horned Grasshoppers (Family: Acrididae) are attracted to light in Surat

Dangs (Gujarat State). Incidentally, not a single species of Longhorned Grasshopper (Family: Tettigoniidae) is listed by them as getting attracted to light. During monsoon or even in postmonsoon period, the most commonly seen Long-horned Grasshoppers coming to light in small numbers are grass dwelling Conocephalus spp.

The occurrence of an uncommon species Mecopoda elongata being attracted to light in such large numbers is noteworthy. It is a very large dark brown species, often with markings as found on decaying leaves. It is sparsely encountered among trees in the plains but not in the open. Thus, its occurrence around Pune region in large numbers is indicative of a population outburst. However, extensive literature search pertaining to the topic of this note was not done. Prolonged monsoon in 1998 may be the possible reason attributed to this outburst.

Interestingly, this species was not observed at light before 12.xi.1998 and its population was seen drastically diminishing thereafter. On the next day, i.e. 13.xi.1998, we observed seven different bird species feeding on these grasshoppers. They were the Indian Myna (two individuals), the Jungle Myna (two pairs), the Common Drongo (two individuals), the Grey Babbler (flock of seven to eight), the White Wagtail (single), the Grey Wagtail (three individuals) and the Indian Robin (two pairs). By evening very few grasshoppers were left in the premises. Some of them left the place during the day and predation by the birds was partly responsible for reduction in their number.

\section{Acknowledgements}

We are thankful to Dr. J.R.B. Alfred, Director, ZSI, Calcutta and Dr. M.S. Pradhan, Sci.SE \& Officer-in-Charge, ZSI, Pune, for facilities and encouragement. We are also grateful to Dr. A.S. Mahabal, Sci-SE, ZSI, Pune for identifying the birds found feeding on the grasshoppers.

\section{References}

Shull, E.M. and N.T. Nadkerny (1967). Insects attracted to mercury vapour lamp in the Surat Dangs, Gujarat State. J. Bombay Nat. Hist. Soc. 64(2): 256-266.

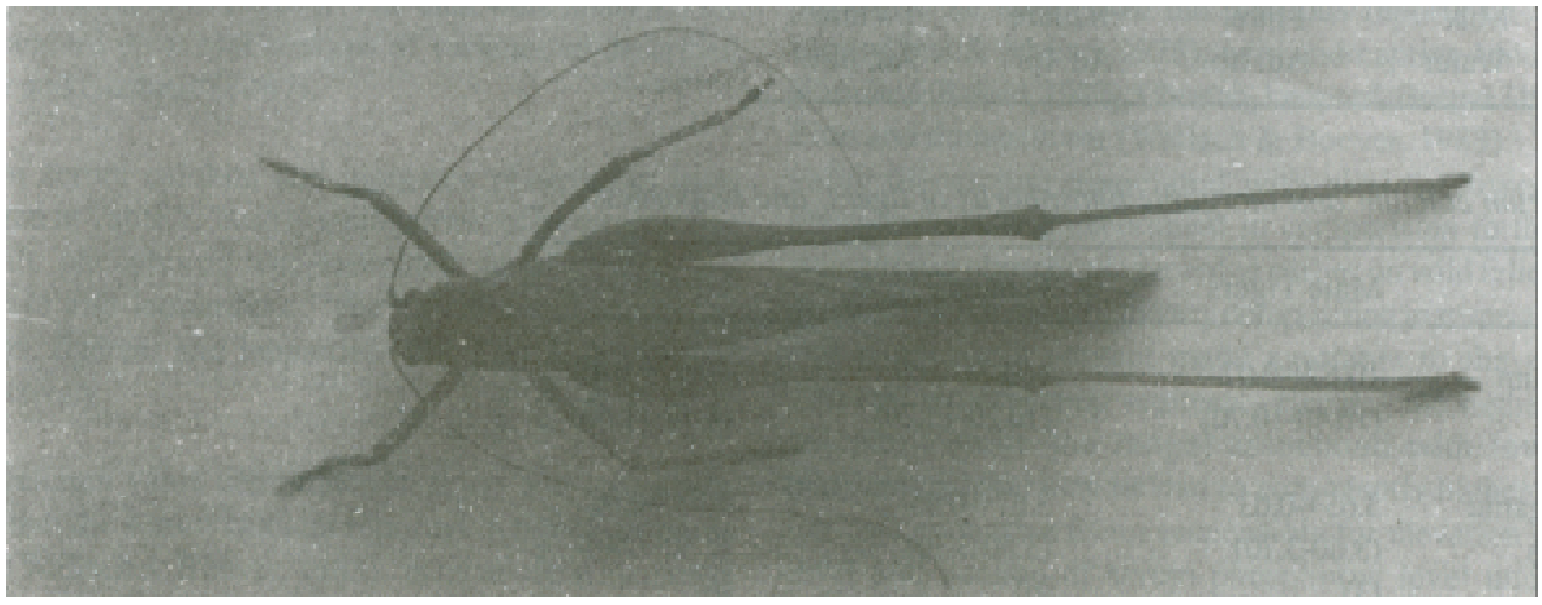

